\title{
Empirical survey on business models of kindergarten farms
}

\author{
Biancamaria Torquati, Costanza Tancini, Chiara Paffarini and Roberta Illuminati
}

\author{
* Correspondence: \\ bianca.torquati@unipg.it \\ Department of Agricultural, Food \\ and Environmental Sciences, \\ University of Perugia, Borgo XX \\ Giugno, 74, 06121 Perugia, Italy
}

\begin{abstract}
The paper presents a study of a new social farming initiative: kindergarten farms. The paper emphasizes the value of potential synergies between the agricultural and the educational service. The two case studies analyzed are high-quality Italian kindergartens supported by a Marche Region project to foster employment in rural areas and improve the quality of life. The entrepreneurial models were investigated using the Business Model Canvas (BMC), which enabled us to examine the economic results of the kindergarten farm, the importance of the farm location, and the role of public decision-makers. The results show that the kindergarten farms offer a new way to achieve economic diversification, to supplement the incomes of rural people, to support exchange between generations, and to reduce the public cost of social services.
\end{abstract}

Keywords: Social farming, Kindergarten farm, Business Model Canvas

JEL: Q120, O180, 1200

\section{Background}

Over the last twenty years different aspects of multifunctional agriculture have been examined and discussed, and many studies have been published on it (see e.g. Renting et al., 2009; Zasada, 2011; Mann and Wüstemann, 2008; Wilson, 2007; Randall, 2002). Various studies have described the increasing diversification in farm activities across Europe, including agri-tourism, care farming, educational activities, biomass production, direct marketing, nature and landscape management, and quality food production (see e.g. Revel et al., 2002; Winter and Turner, 2003; Chaplin et al., 2004). Multifunctional agriculture has developed as a result of a number of wider societal and political transformation processes that have influenced scientific and policy approaches in different ways amongst countries and disciplines (Renting et al., 2009). European agriculture and rural areas are facing multiple socio-economic changes, including a transition from an agriculture-based to a service-based economy. In fact, the image and perception of agriculture and rurality have changed. Farming and rurality are no longer associated with conditions of decline and exclusion, but are perceived as extremely positive realities because of their environmental, social and cultural value (Casini, 2002).

Research about new categories of activities carried out by farms, the decision-making processes of farmers, and the economic results achieved by "taking advantage of the attributes of rurality for economic aims" (Basile and Cecchi, 2001) has become complex 
because of the many functions now attributed to agriculture. In this context of ongoing evolution, Green Care in Agriculture ${ }^{1}$ offers an important connection point between farm activities and these efforts to maintain or promote people's social, physical, mental, and educational well-being (Haubenhofer et al., 2010). Green Care in Agriculture has been defined as "the utilization of agricultural farms, the animals, the plants, the garden, the forest, and the landscape as a base for promoting human mental and physical health, as well as quality of life, for a variety of client groups" (Memorandum of Understanding of COST866 Green Care in Agriculture, in Dessein and Bock, 2010 p.11).

In particular, Green Care embraces the use of farming practices to promote many social goals, such as the rehabilitation, education and care of disadvantaged people, the integration of people with "low contractual capacity" (i.e. those with intellectual and physical disabilities or drug addiction, convicts, and migrants) and the support of specific target groups in rural areas such as children (kindergarten farms) and the elderly.

Green Care is one of the new kinds of activities and services offered by a growing number of farms throughout Europe (eg. Di lacovo and O' Connor 2009; Van der Ploeg and Marsden, 2008; Wiskerke, 2009) and for this reason it is interesting to investigate the costs and benefits of these activities for farmers and society as a whole.

In this context of using farms as settings for social services, our paper presents a study of a new social farming initiative: kindergarten farms or nursery-school farms, which are educational childcare facilities in a farm setting for children from 1 to 3 years old. Besides their important function of caring for children, kindergarten farms can also shape future generations' eating habits and attitudes to farming. Children learn to appreciate and respect nature and agriculture; they learn about a healthy diet, and the link between agricultural products and food, and come to appreciate the social function of farmers. This is a crucial aspect of care farming in general, as it educates current and future consumers about sustainable production and consumption, an indispensable part of building sustainable food systems (FAO, 2014).

Kindergarten farms offer a number of benefits. While school trips to farms enable children to learn specific information about agriculture, the environment, and nutrition (Canavari et al. 2011), youngsters may experience them as an unusual and exceptional event that has no connection with their daily life and world (Montari, 2001). Instead, day to day experience of a working farm has a much more profound impact on children. Moreover, kindergarten farms meet the need for more childcare facilities in marginal areas with low population density, such as mountainous or highly rural zones. These activities also afford a new way to achieve economic diversification, to supplement the incomes of rural people, to promote female entrepreneurship and to help rural women reconcile work and motherhood (Bertolino et al., 2012). Kindergarten farms are a phenomenon that is spreading rapidly in Northern Europe, especially in Germany.

In Italy, specifically in such regions as Veneto, Piemonte, Trentino, Friuli and the Marche, over one hundred initiatives have already been established.

The spread of kindergartens farms has been more successful in the regions where policy makers have passed laws to regulate accreditation and other details (Rete Rurale Nazionale 2007-2013- Task Force Pari Opportunità e Giovani 2009).

This study focuses on the main characteristics of kindergarten farms, and examines the value of potential synergies between the worlds of agriculture and education. We look at entrepreneurial models, economic results, types of farming location, and the 
role of the public decision-maker. Moreover, the study proposes to use the Business Model Canvas (BMC) as a tool for analysing multifunctional farming enterprises.

Several studies illustrate how the BMC can be particularly useful in classifying an enterprise and analysing its performance, though they also highlight some interpretative limitations inherent in this approach (Lambert and Davidson, 2013; George and Bock, 2011; Zott et al., 2011; Baden-Fuller and Morgan, 2010; DaSilva and Trkman, 2014; Teece, 2010; Morris et al., 2005; Shafer et al., 2005). In particular, George and Bock (2011) highlight the heterogeneity of the fields of application but criticize the absence of links between research theme, methodologies and findings. Lambert and Davidson (2013), in their literature review on business models, underline some research fields (business and management, information systems and biotechnology) where BMC can be successfully applied. In this context, our study tests the usefulness of the BMC tool for research on agricultural green care.

\section{Methods}

The study analyzed two Italian kindergarten farms that are part of the Marche Region “Modello Agrinido di Qualità" project (D.G.R. n. 722 on 24th May 2011), in order to investigate entrepreneurial models, economic results, importance of farming location, and the role played by the policy maker.

To collect the case study data, we used a questionnaire about structural and economic aspects, private and social benefits, and business organization. In March 2014 we interviewed six farmers using the standardized questionnaire developed by a working group on "Entrepreneurial Models of Urban Agriculture" of the COST Action Urban Agriculture Europe (Alfranca et al., 2013). The questionnaire addresses the overall functioning of the farm and asks for both quantitative and qualitative information and data about: i) the company profile (structural features of enterprise); ii) geographical situation (orography, landscape, ecological situation); iii) the main business activities (characteristics of the kindergarten - children hosted, building, activities, products and services of the farm); iv) markets and marketing (target, offer, channels, local and national markets, proposed value); v) institutional environment (public support); vi) success factors of the enterprise; vi) problems of the activity and; vii) societal benefits (increase of sales, job creation, job services, educational and social activities, open space management, agro-biodiversity, preserving historical farm buildings).

We analyzed the data collected during the interviews using the BMC proposed by Osterwalder and Pigneur (2010) in order to identify the entrepreneurial models used by the kindergarten farms, describe their economic results, and formulate policy suggestions.

In particular, the BMC was chosen because "it describes, as a system, how the pieces of a business fit together" (Magretta, 2002, p.6) and at the same time "focuses on factors internal to the enterprise" (Lambert and Davidson, 2013, p. 669). These characteristics together with its simplicity and its practice-oriented nature (Ching and Fauvel, 2013), make it an extremely useful tool for analysing and describing the multifunctional farming model.

According to Osterwalder and Pigneur "a business model describes the rationale of how an organization creates, delivers, and captures value" (Osterwalder and Pigneur, 2010 p.14). They described a business model through nine basic building blocks that 
"cover the four main areas of a business: customers, offer, infrastructure, and financial viability" (Osterwalder and Pigneur, 2010 p.15). These nine blocks are Customer Segments, Value Propositions, Channels, Customer Relationships, Revenue Streams, Key Resources, Key Activities, Key Partnerships and Cost Structure.

According to Mahadevan, the core elements of a business model are the three questions proposed by Markides (2000): "who?", “what?" and "how?" (Mahadevan, 2004 p.2). The "who" identifies customers and their need, and thus the target group for the business; the "what" specifies the value offered, or the "value proposition"; and the "how" refers to the operational aspects of the business. Lundy et al. (2012) added a new question, "how much?", to describe revenue and cost. Pölling and Lorleberg (2014) suggest linking the four fundamental questions noted above with the four main areas of Osterwalder and Pigneur: "who? - customers", "what? - offer", "how - infrastructure" and "how much? financial viability".

In our opinion, two other areas, the supplier and relationships, should also be taken into account to properly analyse social farming. The supplier is the person who organises the key resources and coordinates with all the partners. By relationships we mean the farm's networks, that is, all the contacts with customers and partners. Along these lines, Morris et al. (2005, p.5) define the main components of a business model, in terms of two questions: first, "what is our source competence?", that is, they ask who supplies the skills in the business, and second "how do we competitively position ourselves?", that is, they ask about the business strategy for competing. Similarly, Shafer et al. (2005) also identified the "value network", the relationships with suppliers and customers as a component of a business model (and this includes customer information, information flows, and product/service flows). Another area to be taken into account in using the BMC to analyse social farming is the issue of the for-profit or not-for-profit nature of the enterprises. According to Osterwalder and Pigneur (2010), the application of the $\mathrm{BMC}$ is not limited to for-profit corporations. In particular, the authors propose two other building blocks ${ }^{2}$, social costs and social benefits, in order to do a complete analysis, describing the outcomes of the business activities. In the case of social farming, the block of social costs is the public and private support necessary to ensure the social service, while the block of social benefits is how much government institutions save by activating a social service through social farming.

Our proposal of a BMC for social farming is shown in Fig. 1.

The figure presents a combination of the four essential questions, the six main areas and the eleven blocks that are described in the main aspects. The eleven basic building blocks should be analysed in the following sequence in order to progress systematically: 1. Customer Segments, 2. Value Propositions, 3. Customer Relationships, 4. Channels, 5. Revenue Streams, 6. Key Resources, 7. Key Activities, 8. Key Partnerships, 9. Cost Structure, 10. Social Cost, 11. Social Benefits. This figure offers a systematic and uniform way to understand the business model of each farm, and compare them to each other.

Among the various types of care farming, the kindergarten farm presents particular characteristics. In terms of the eleven blocks: 1) its customer segments are families with children between the ages of 1 and 3 years who live in peri-urban or rural areas; 2) it proposes services that have market value (farm products) and social value (education) (value proposition, in our business model); 3) it attracts new customers who are not those traditionally associated with farms; 4) it uses innovative channels to reach new 


\begin{tabular}{|c|c|c|c|c|c|}
\hline $\begin{array}{c}\text { KEY } \\
\text { PARTENERSHIPS } \\
(8)\end{array}$ & $\begin{array}{c}\text { KEY } \\
\text { ACTIVITIES } \\
(7)\end{array}$ & \multicolumn{2}{|c|}{$\begin{array}{c}\text { VALUE } \\
\text { PROPOSITIONS } \\
(2)\end{array}$} & $\begin{array}{c}\text { CUSTOMER } \\
\text { RELATIONSHIPS } \\
(3)\end{array}$ & $\begin{array}{c}\text { CUSTOMER } \\
\text { SEGMENTS } \\
\text { (1) }\end{array}$ \\
\hline $\begin{array}{l}\text { Who? Suppliers } \\
\text { How? Relationships }\end{array}$ & $\begin{array}{l}\text { What? Offer } \\
\\
\text { The most } \\
\text { important } \\
\text { activities a } \\
\text { company must do } \\
\text { to make its } \\
\text { business model } \\
\text { work }\end{array}$ & \multirow{3}{*}{\multicolumn{2}{|c|}{$\begin{array}{l}\text { The bundle of } \\
\text { products and } \\
\text { services that } \\
\text { create value for a } \\
\text { specific customer } \\
\text { segment }\end{array}$}} & $\begin{array}{l}\text { How? Relationships } \\
\\
\text { The types of } \\
\text { relationships a } \\
\text { company } \\
\text { establishes with } \\
\text { specific customer } \\
\text { segments }\end{array}$ & Who? Customers \\
\hline & $\begin{array}{c}\text { KEY } \\
\text { RESOURCES } \\
(6) \\
\text { How? } \\
\text { Infrastructure }\end{array}$ & & & $\begin{array}{c}\text { CHANNELS } \\
\text { (4) } \\
\text { How? Infrastructure }\end{array}$ & \\
\hline $\begin{array}{c}\text { The network of } \\
\text { suppliers and } \\
\text { partners that make } \\
\text { the business model } \\
\text { work }\end{array}$ & $\begin{array}{l}\text { The most } \\
\text { important assets } \\
\text { required to make } \\
\text { a business }\end{array}$ & & & $\begin{array}{l}\text { How a company } \\
\text { communicates with } \\
\text { and reaches its } \\
\text { customer segments } \\
\text { to deliver a value } \\
\text { proposition }\end{array}$ & $\begin{array}{l}\text { The different } \\
\text { groups of people } \\
\text { or organizations } \\
\text { that the company } \\
\text { aims to reach and } \\
\text { serve by its } \\
\text { products and } \\
\text { services }\end{array}$ \\
\hline \multicolumn{3}{|c|}{$\begin{array}{c}\text { COST STRUCTURE } \\
(9)\end{array}$} & \multicolumn{3}{|c|}{$\begin{array}{l}\text { REVENUE STREAMS } \\
\text { (5) }\end{array}$} \\
\hline \multicolumn{3}{|c|}{ All costs incurred to operate a business model } & \multicolumn{3}{|c|}{ How much? Financial viability } \\
\hline \multicolumn{3}{|c|}{$\begin{array}{l}\text { SOCIAL COSTS } \\
(10)\end{array}$} & \multicolumn{3}{|c|}{$\begin{array}{l}\text { SOCIAL BENEFITS } \\
\text { (11) }\end{array}$} \\
\hline \multicolumn{3}{|c|}{ How much? Financial viability } & \multicolumn{3}{|c|}{ How much? Financial viability } \\
\hline \multicolumn{3}{|c|}{$\begin{array}{c}\text { Public support necessary to ensure that social } \\
\text { service }\end{array}$} & \multicolumn{3}{|c|}{$\begin{array}{l}\text { How much the Institution saves activating a } \\
\text { social service through a social farming }\end{array}$} \\
\hline
\end{tabular}

Source: Own figure based on: Osterwalder and Pigneur, 2010; Lundy et al., 2012; Henriksen et al., 2012; Pölling and Lorleberg, 2014.

Fig. 1 Business Model Canvas for social farming

customers, such as environmental and social associations, direct sales and regional projects; 5) its revenue streams come from families and public institutions; 6) its social benefits are measurable to some degree, in that the cost per child for municipalities to subsidise these private initiatives is significantly less than the cost per child of their own municipal early childhood facilities; 7) it develops in a peri-urban or rural farm using both internal resources, namely family members who work the farm, and their land, buildings and machinery, and external resources, that is the teachers they hire (key resources, in our business model); 8) its key functions are educational, through hands-on activities with plants and animals; 9) its key partnerships are with local and regional government entities and various environmental and business associations that 
previously may not have dealt specifically with farms; 10) its cost structure includes expenses not traditionally associated with farms; 11) its social costs, the amount public institutions contribute to support the service, are measurable.

\section{Case studies}

Interviews were conducted on all six farms that in 2014 were part of the "Quality Kindergarten Network" Project (Progetto Rete Agrinido di Qualità), a collaboration between the Marche Region Department of Agriculture and the Montessori Foundation of the city of Chiaravalle.

The project finances new high-quality kindergartens in mountainous and disadvantaged areas where education services are often limited, and in peri-urban areas, which instead have sufficient services, with the objectives of fostering employment in rural areas and improving the quality of life. The project seeks to develop new forms of occupation and new sources of agricultural income, as well as to stimulate a process of cultural re-assessment and help the farming sector recover the social function it has served for centuries.

In particular, we examined two case studies of the six kindergarten farms that are part of the "Quality Kindergarten Network" Project, chosen because their characteristics summarize the main models of the group, and also because of their location, number of children hosted and business activities.

The case study A farm is located in a mountainous rural area near the Monti Sibillini National Park, while the case study B farm is in a hilly coastal area near a city. In 2013-2014, farm A hosted 8 children, whereas farm B hosted 14. In terms of business activities, both farms are multifunctional. However, while farm A has diversified its activities to include social and environmental services, Farm B, instead, still focuses on traditional farming because its vicinity to a city makes it feasible to sell products directly to customers.

On the basis of the BMC method, it can be said that the particular characteristics of case study A are its:

Customer segments: the farm hosts not only children from 1 to 3 years of age, but also those from 4 to 6 years old and young students from 6 to 16 years old for afterschool activities and summer courses; in addition, it hosts disabled people who live in the rural area. Moreover, the farm offers services to rural tourists, other farms, public and private agencies and people asking for local organic foods.

Value proposition: first of all, the farm produces and sells organic vegetables, fruit, cereals, and poultry to customers directly. Furthermore, it offers a number of services, such as education of children, environmental education through a WWF Centre, advice and training on environmental sustainability, assistance of people with disabilities, and farm holidays.

Customer relationship: the strong point of the farm is the personal relationship it maintains with all its customers.

Channels: the farm uses several channels in order to reach new customers, such as environmental, social and agricultural associations, direct sales from its farm shop and institutional communication of regional projects, in particular, Marche Region advertising about its social service projects in the form of newspaper and magazine articles. 
Revenue streams: the estimate of revenues shows the importance of the farm's combination of traditional activities with other endeavours. In 2013 it earned 20,000 euro from sales of its organic products and it benefitted from its diversification. it took in 28,000 euro from agri-tourism services, 28,000 euro for educational services for children and 4,000 euro for the services for older students and it earned 4,000 euro for providing social services for disabled people. Also, the farm received 22,000 euro in government subsidies for all its activities.

Social benefits: the municipality saves 4,624 euro per child by subsidizing this kindergarten farm rather paying the higher cost of having these children enrolled in its own municipal facilities ${ }^{3}$.

Key resources: the family works the farm and staffs the agritourism business, the services for the disabled and the educational services for children 3-16, and owns the land, buildings and machinery. The teacher is the only external resource.

Key activities: the farm raises organic products and sells them directly to customers. It is multifunctional in the sense that it also offers agri-tourism services, the kindergarten, environmental education through a WWF Centre, and assistance for people with disabilities.

Key partnership: The Marche Region is the most important partner, followed by the WWF, the European Network of Eco-museums, the Monti Sibillini National Park, Fairtrade Italy, the Mediterranean Association of Organic Agriculture, the Mediterranean Institution of Certification, and the towns of San Ginesio and Cessapalombo.

Costs Structure: the estimate of costs shows the entity of the farm's traditional multifunctional activities (24,000 euro to produce organic food and 18,000 euro in management costs for agri-tourism) and also highlights the substantial expenditures for the new multifunctional activities (16,500 euro for kindergarten management, 15,000 euro for the kindergarten teacher's salary, and 2,500 euro for management costs of the farm's events and shop).

Social costs: the Marche Region government subsidizes the kindergarten farm 2,875 euro per child ${ }^{4}$ (the kindergarten farm hosts 7 children per year), and a family choosing a kindergarten farm pays 1,804 euro a year more than a family choosing a public kindergarten.

The particular characteristics of case study B are:

Customer segments: the farm hosts not only children from 1 to 3 years of age, but also children from 4 to 6 years old and young students from 6 to 16 years old for after-school activities and summer courses. Moreover, the farm meets the needs of customers who want to taste and buy local products at its farm shop/tasting room, and attend cooking and painting courses.

Value proposition: the farm produces and sells vegetables, olive oil, and beef directly to its customers, and also offers education services for children, entertainment during the holidays and a number of training seminars.

Customer relationship: for farm B as well, personal relationships are the strong point. The farm nurtures personal relationships with all its customers.

Channels: the most important advertising channels for the farm are direct sales from its farm shop and institutional communication of regional projects. 
Revenue streams: the estimate of revenues shows the importance of direct sales. In 2013 it earned 130,000 euro from meat sales, 4,000 euro from its olive oil, and 30,000 euro from events that offer consumers the opportunity to taste and buy food from local farms. Moreover, it highlights the value of its educational services (56,000 euro), on-farm courses (6,000 euro) and the government subsidies it receives for farm activities and the kindergarten (22,000 euro).

Social benefits: in this case, the municipality saves 4,981 euro per child by subsidizing this kindergarten farm rather than pay the higher cost of having these children enrolled in its own municipal facilities.

Key resources: the farm employs the family members and external qualified workers, while the land, building and machinery belong to the farm (internal resources). The kindergarten needs 2 teachers (external resources).

Key activities: the farm raises cattle and produces olive oil, and sells its products directly to consumers. The main services offered are the kindergarten, events that offer consumers the opportunity to taste and buy food from local farms, and cooking and painting courses.

Key partnership: The Marche Region is the most important partner, followed by the association of professional famers.

Costs Structure: the estimate of costs shows the importance of agricultural production and direct sales. In 2013 the management costs for raising cattle were 60,000 euro, while those for producing olive oil were 3,000 euro, and management costs for the farm shop were 5,000 euro. The expenses for external resources were 30,000 euro in salaries for the two kindergarten teachers, and 80,000 euro in salaries for its qualified workers; expenses for educational activities were 30,000 euro in management costs for the kindergarten, and those for other farm activities were 6,000 euro for management of farm events and the tasting room.

Social costs: in this case, the Marche Region government subsidizes the kindergarten farm 2,500 euro per child (the kindergarten farm hosts 14 children per year), and as for case study A, each family pays 1,804 euro a year more than a family choosing a public kindergarten.

\section{Results and discussion}

The case studies exemplify fruitful synergies between the worlds of agriculture and education. In particular, the network of quality kindergartens on farms has developed because of: 1) the Marche Region's attention to agricultural and social problems and its willingness to experiment with new practices that combine different areas of expertise; 2) the Montessori method, which encourages the development of the child's will and recognizes the value of nature in children's education; 3) family farms where culture and experience are preserved and handed on (Van der Ploeg, 2014) to a new generation of agricultural entrepreneurs who care about quality of life for themselves and others.

The study of the farms' entrepreneurial models through BMC has highlighted the growing complexity in their management, with the evolution in their customer segments and relationships, value propositions, key partnerships, key activities and resources.

The complexity of these new entrepreneurial models prompts another question: what types of farming do they carry out? Traditionally, farming types have been identified according to the structure the business adopts in relation to size, production factors used, 
the relationship between the entrepreneur and production factors (Serpieri, 1929), the relationships among farm business, labour and property (Medici, 1951), multiple activities of family farming (Marinelli et al., 1998), and the dynamic relationships between farm business and the agro-food system (Mantino, 1995). Today other classification criteria are probably called for, such as family farming, farm functions, location, customer segments, and key partnerships (Table 1).

The study shows significantly positive economic results for these ventures. The net farm income per family worker was 15,000 euro in case study A and 47,500 euro in case study B. This result demonstrates that farms can improve earnings from their labour when they engage in multiple functions and when they receive adequate financial support from public institutions. The fact that the farm close to the city achieved better results than the one in a rural area is due to several factors: it is located in more densely populated area, it produces beef and olive oil, which are high-value products, and its social services are tailored to meet the needs of families with children.

The role of Marche Region government subsidies merits special attention. The average annual government subsidy per child was 2,875 euro in case study A, which hosted

Table 1 Comparison between two case studies

\begin{tabular}{|c|c|c|}
\hline Characteristics & Case study A & Case study B \\
\hline Subject & Professional agriculture & Professional agriculture \\
\hline Location & Rural area & Peri-urban area \\
\hline Utilized agricultural area, ha & 8 & 50 \\
\hline Head of cattle & 0 & 100 \\
\hline Asset value, euro & 260,000 & $1,550,000$ \\
\hline Estimated revenue streams, euro & 84,000 & 226,000 \\
\hline Revenue from production & $24 \%$ & $59 \%$ \\
\hline Revenue from social service & $43 \%$ & $25 \%$ \\
\hline Revenue from recreational service & $33 \%$ & $16 \%$ \\
\hline Number of paid workers & 1 & 6 \\
\hline Number of family workers & 2 & 2 \\
\hline Number of volunteers & 1 & 0 \\
\hline Functions & Case study A & Case study B \\
\hline Food production & yes & yes \\
\hline Social- rehabilitation and care & yes & no \\
\hline Social and educational & yes & yes \\
\hline Tourist and recreation & yes & no \\
\hline Environmental and biodiversity & yes & no \\
\hline Direct sales of farm products & yes & yes \\
\hline Social, leisure and well-being & no & yes \\
\hline Economic results & Case study A & Case study B \\
\hline Estimated net farm income, euro & 30,000 & 95,000 \\
\hline Estimated net farm income per family worker, euro & 15,000 & 47,500 \\
\hline $\begin{array}{l}\text { Amount the government saves per child by } \\
\text { subsidizing kindergarten farm, euro }\end{array}$ & 4,624 & 4,981 \\
\hline Increase in the annual fee paid by family, euro & 1,804 & 1,804 \\
\hline
\end{tabular}


8 children in its rural kindergarten, while it was 2,500 euro in case study B, located close to the city, which hosted 14 children in its kindergarten. These values include a one-time contribution of 20,000 euro per farm to cover part of the investment required to adapt farm buildings for use as kindergarten facilities and, the annual contribution of 15,000 euro for management costs.

Given that Italian municipalities spend on average 8,923 euro per child to run their own nursery schools, they save, respectively, 6,353 and 7,851 euro on those children who attend kindergarten farms $\mathrm{A}$ and $\mathrm{B}$.

Instead, when municipalities subcontract kindergarten services to third parties, their annual average subsidies per child amount to 4,239 euro. Their subsidies to kindergarten farms A and B are significantly less expensive: compared to the cost of third-party kindergartens, municipalities still save per child 1,699 euro and 3,167 euro respectively in kindergarten farms A and B. Therefore, for the municipalities, kindergarten farms are more advantageous economically.

For families, instead, the annual cost for kindergarten farms, 3,600 euro per child, is higher than that for kindergartens run by the city or third-parties (400 euro per month instead of 200). Despite this, the overall balance is positive, considering the saving to public administrations and the optimized use of public funds to offer excellent Montessori educational services to families in rural or disadvantaged areas and to improve the economic viability of farm life.

Finally, it should be noted that the government subsidies are more important for the kindergarten farms in rural areas. While kindergarten farm B near a city had no difficulty attracting its 14 clients, farm B in a rural area has a smaller population of children to draw upon, and enrolled only half the number of clients. Government assistance has been vital to making this endeavour economically viable.

\section{Conclusions}

In this study we describe how new synergies between farmers, educators, associations, and local and regional governments have created kindergarten farms that foster the transmission of farm wisdom and experience to younger generations, enable farm families to stay on their land and prosper, and offer high quality Montessori education to areas poorly served by traditional facilities.

Montessori kindergartens on farms can exploit the innumerable opportunities for early-childhood learning and development afforded by their setting, just as educational services on farms for older children offer great possibilities for didactic enrichment.

According to the results of our case studies, the synergy between education and agriculture also yields significantly positive economic results for municipalities and farmers. Thus this kind of multifunctional approach to farm life can be considered a new option for economic diversification in rural areas that enables farms to augment their incomes and thus be able to continue their valuable traditional activities as well. Public decision makers play a primary role, inasmuch as they can formulate legislation to support this new activity and work in the best interests of their constituents. In this context, EU policies, particularly the 2014-2020 Rural Development Programme (RDP) for the regions, will bring crucial support for these new activities of social farming.

A number of conclusions can be drawn from the present analysis. First, the quantification of the costs and benefits reveals the increased costs borne by families, and thus 
a shift from public toward private subsidies for education. This situation may well prove unsustainable for families and consequently unsuitable for the development of rural areas in which average family incomes already tend to be lower than those of residents in urban or peri-urban areas, and where there is less need to improve quality of life. Second, the farms that offer social services using their internal spaces and resources, such as the kindergarten farms, suffer from the lack of explicit recognition of the service they provide. Currently, this recognition only occurs through the passage of regional laws. Instead, there should be greater integration between agricultural and social policies to guide the economic and social components in the processes of creating value. Third, the innovative components of social agriculture have been of great importance in terms of processes of creation of value in the farms, improved allocation of public funds, and strengthening of relationships between rural and peri-urban areas, three factors which should be the building blocks for ensuring that younger generations of farming families can afford to stay on their land and thus offer continuity to the agricultural sector. Finally, the complexity of the multifunctional firms requires flexible and innovative new analytical tools. In this study, the BMC has proven useful for describing, interpreting and comparing practices of social agriculture that are quite diversified in form, organization, objectives and type of user reached. Its use can be proposed for all contexts of multifunctional agriculture.

\section{Endnotes}

${ }^{1}$ In some countries, it is called green care, in others 'social farming' or 'care farming' (Hine et al., 2008; Di Iacovo and O'Connor, 2009; Sempik et al., 2010).

${ }^{2}$ Osterwalder and Pigneur (2010) propose a BMC for so-called "triple bottom line" business model. This category of beyond-profit models takes account environmental, social and financial cost. Therefore the authors "extend the Canvas with Blocks illustrating two outcomes; 1) the social and environmental cost of a business model (i.e. its negative impact), and 2) the social and environmental benefits of a business model (i.e. its positive impact).

${ }^{3}$ In Italy the public kindergartens (almost 153,000 children enrolled) absorb an average annual cost by municipalities of 7,481 euro and an average contribution from the families of 1,796 euro per child (ISTAT, 2014).

${ }^{4}$ Overall and for the first three years of the project, the Marche Region has granted to each farm a grant of 50,000 euro, of which 20,000 euro for the adjustment of spaces and structures and 30,000 euro for the management costs of first two years of activity.

Competing interests

The authors declare that they have no competing interests. 


\section{References}

Alfranca O, Anderson G, Berntsen I, Branduini P, Koleva G, Lorleberg W, Mendes Moreira P, Ong T, Paulen O, Pölling B, Spornberger A, Torquati B, VanderSchans JW, Weissinger H (2013) Standard questionnaire for urban agriculture case studies. Working paper for COST-Action Urban Agriculture Europe. Chapter "Wiki" - Subchapter "WG 3: Entrepreneurial models of Urban Agriculture" (March 18th, 2014)., http://www.urbanagricultureeurope.la.rwth-aachen.de

Baden-Fuller C, Morgan MS (2010) Business Models as Models. Long Range Plann 43:156-171

Basile E, Cecchi C (2001) La Trasformazione post-industriale della campagna. Dall'agricoltura ai sistemi locali rurali, Collana Sviluppo Locale, Rosenberg \& Sellier, Torino

Bertolino F, Perazzone R, Piccinelli A (2012) Extraterrestri in campagna: quando insegnanti e ragazzi sbarcano in fattoria didattica., Negretto Editore

Canavari M, Huffaker C, Mari R, Regazzi D, \& Spadoni R (2011) Educational farms in the Emilia-Romagna region: their role in food habit education. In: Sidali K L, Spiller A, \& Schulze B. (eds.) Food, Agri-culture and Tourism: Linking Local Gastronomy and Rural Tourism: Interdisciplinary Perspectives. Springer, Heidelberg

Casini L (2002) Funzioni sociali dell'agricoltura e nuove tipologie d'impresa. In: Centro Studi Stampa 2P (ed) Atti del XXXIX Convegno di Studi della SIDEA, Nuove tipologie di impresa nell'agricoltura italiana, Firenze, 12-14 settembre, 3-58

Chaplin H, Davidova S, Gorton M (2004) Agricultural adjustment and the diversification of farm households and corporate farms in central Europe. J Rural Stud 20:61-77

Ching HY, Fauvel C (2013) Criticisms, variations and experiences with business model canvas. Eur J Agri Forestry Res 1(2):26-37

DaSilva CM, Trkman P (2014) Business Model: What It Is and What It Is Not. Long Range Plann 47:379-389

Dessein J, Bock BB (2010) The Economics of Green Care in Agriculture. COST Action 866, Green Care in Agriculture. Loughborough University Press, Loughborough

Di lacovo F. and O' Connor D (Eds.) (2009) Supporting policies for Social Farming in Europe, Arsia, Firenze, Italy (http://sofar.unipi.it). Accessed 20 July 2014.

FAO (2014) Social Farming (also called care farming): an innovative approach for promoting women's economic empowerment, decent rural employment and social inclusion. What works in developing countries? Proceedings of Global Forum on Food Security and Nutrition, Collection of contributions received, Discussion No. 100 from 15 April to 16 May 2014. http://www.fao.org/fsnforum/forum/discussions/care-farming. Accessed 20 July 2014.

George G, Bock AJ (2011) The Business Model in Practice and its Implications for Entrepreneurship Research. Enterp Theory Pract 35(1):83-111

Haubenhofer D, Elings M, Hassink J, Hine R (2010) The development of green care in Western European countries. Explore 6(2):106-111

Hine R, Peacock J, Pretty J (2008) Care Farming in the UK: contexts, benefits and links with therapeutic communities. Therapeutic Comm 29(3):245-260

ISTAT (2014) L'offerta comunale di asili nido e altri servizi socio-educativi per la prima infanzia, http://www.istat.it/it/ archivio/129403. Accessed 20 June 2014.

Lambert SC, Davidson RA (2013) Applications of the business model in studies of enterprise success, innovation and classification: An analysis of empirical research from 1996 to 2010. Eur Manag J 31:668-681

Lundy M, Becx G, Zamierowski N, Amrein A, Hurtado JJ, Mosquera EE, Rodriguez F, (2012) Link Methodology-A Participatory Guide to Business Models that Links Smallholders to Markets, Centro Internacional de Agricultura Tropical (CIAT) Cali (CO) 171p. CIAT Publication No. 380 https://cgspace.cgiar.org/handle/10568/49605. Accessed 10 May 2014

Magretta J (2002) Why business models matter. Harv Bus Rev 80(5):86-93

Mahadevan B (2004) A framework for business model innovation. Paper presented at IMRC Conference, Bangalore, 16-18 December 2004

Mann S, Wüstemann H (2008) Multifunctionality and a new focus on externalities. J Socio-Econ 37(1):293-307

Mantino F (1995) Impresa agraria e dintorni. INEA, Roma

Marinelli A, Sabbatini M, \& Turri E (1998) Le tipologie delle aziende agricole italiane tra professionalità e accessorietà, Rivista di economia agraria, 3,315-361.

Markides C (2000) All the Right Moves: A Guide to Crafting Breakthrough Strategy. Harvard Business School Press, Boston MA

Medici G (1951) I tipi d'impresa nell'agricoltura italiana. INEA, Roma

Montari L (2001) Per una pedagogia ecologica: prospettive tecniche e ricerche empiriche sull'educazione ambientale, Volume 284 di Didattica viva, La Nuova Italia

Morris M, Schindehutte M, Allen J (2005) The Entrepreneur's Business Model: Toward a Unified Perspective. J Business Res 58:726-735

Osterwalder A, Pigneur Y (2010) Business model generation: a handbook for visionaries, game changers, and challengers. Wiley, Hoboken

Pölling B, Lorleberg W. (2014) Methodology proposal for case studies about business models, success factors and societal benefits of urban and peri-urban agricultural enterprises and projects, Working Paper COST-Action Urban Agriculture Europe, Chamber of Agriculture North-Rhine Westfalia \& South Westfalia University Of Applied Sciences, March 2014

Randall A (2002) Valuing the outputs of multifunctional agriculture. Eur Rev Agri Econ 29(3):289-307

Renting H, Rossing WAH, Groot JCJ, Van der Ploeg JD, Laurent C, Perraud D, Stobbelaar DJ, Van Ittersum MK (2009) Exploring multifunctional agriculture A review of conceptual approaches and prospects for an integrative transitional framework. J Environ Manag 90:S112-S123

Rete Rurale Nazionale 2007-2013- Task Force Pari Opportunità e Giovani (2009) Gli agri-asili:qualità della vita nelle aree rurali, Rete Rurale Nazionale 2007-2013

Revel A, Roux B, Bonnafous P, Ly B, Fiack E (2002) Multifonctionnalité des systèmes diversifies dans les exploitations agricoles du Languedoc Roussillon. In: Actes du colloque international SFER «La multifonctionnalité de l'activité agricole et sa reconnaissance par les politiques publiques, Bonnafous P, Ly B., pp 721-744 
Sempik J, Hine R, Wilcox D (2010) Green Care: A Conceptual Framework, A Report of the Working Group on the Health Benefits of Green Care, COST Action 866. Green Care in Agriculture, Loughborough. Centre for Child and Family Research, Loughborough University, Loughborough

Serpieri A (1929) Guida a ricerche di economia agraria. Libreria internazionale F.lli Treves dell'Ali, Roma

Shafer SM, Smith HJ, Linder JC (2005) The power of business models. Bus Horiz 48(3):199-207

Teece DJ (2010) Business Model, Business Strategy and Innovation. Long Range Plann 43:172-194

Van der Ploeg JD (2014) Dieci caratteristiche dell'agricoltura familiare. BioAgricoltura, n 143-144:28-31

Van der Ploeg JD, Marsden T (2008) Unfolding Webs. The Dynamics of Regional Rural Development. Van Gorcum, Assen

Wilson GA (2007) Multifunctional agriculture: a transition theory perspective., CABI

Winter M, Turner M (2003) Farm Diversification in England 2002., Centre for Rural Research, University of Exeter and Rural and Tourism Research Group, University of Plymouth

Wiskerke JSC (2009) On regions lost and regions regained: reflections on the alternative food geography and sustainable regional development. Int Planning Studies 14(4):369-387

Zasada I (2011) Multifunctional peri-urban agriculture - A review of societal demand and the provision of goods and services by farming. Land Use Policy 28:639-648

Zott C, Amit R, Massa L (2011) The Business Model: Recent Developments and Future Research. J Manag 37(4):1019-1042

\section{Submit your manuscript to a SpringerOpen ${ }^{\circ}$ journal and benefit from:}

- Convenient online submission

Rigorous peer review

- Immediate publication on acceptance

- Open access: articles freely available online

- High visibility within the field

- Retaining the copyright to your article

Submit your next manuscript at $>$ springeropen.com 